\title{
Dual Specificity Protein Kinase TTK
}

National Cancer Institute

\section{Source}

National Cancer Institute. Dual Specificity Protein Kinase TTK. NCI Thesaurus. Code C30147.

Dual specificity protein kinase TTK (857 aa, $\sim 97 \mathrm{kDa}$ ) is encoded by the human TTK gene. This protein is involved in mitotic checkpoint regulation. 